\title{
Differences Of Sexual Assertiveness Between Javanese And Bataknese Adolescent Girls
}

\author{
Indri K. Nasution', Liza Marini'2, Rahma Yurliani ${ }^{3}$ \\ Department of Developmental Psychology \\ University of Sumatera Utara, Medan, Indonesia \\ ndi.kemala@gmail.com
}

\begin{abstract}
Abtract - This study was aimed to determined the difference of sexual assertiveness between Javanese and Bataknese adolescent girl. Sample in this research consist of 678 adolescent girl, where 348 Javanese adolescent girl and 330 Bataknese adolescent girl that have been selected using incidental non probability sampling, aged 15-18 years and live in Medan. Data for this study were obtained by using Skala Asertivitas Seksual untuk Perempuan Indonesia (SASPI or Sexual Assertiveness Scale for Indonesian Women) developed by Lubis and Oryza based on Sexual Assertiveness Scale (SAS). The questionnaires consisted of two dimensions, initiative and rejection. Data analysis technique using ttest (independent sample tes). The results showed that $\mathrm{T}$ value is 0,310 with value of significant is 0,757 , so the significance value of more than $0,05(0,757>0,05)$. It means there is no difference in sexual assertiveness between Javanese and Bataknese adolescent girl.
\end{abstract}

Keywords: Sexual assertiveness, Javanese and Bataknese adolescent girls

\section{INTRODUCTION}

Adolescent is a figure that is loaded with various problems. Almost every aspect of life which adolescents passed through always brings up problems. One of the globalized social problems today is free sex problem which occurs among many adolescent. Sexual issues commonly faced by adolescents is sexual drive that already increased while normatively they are not married, they are not allowed to have sexual intercourse (Sarwono, 2000). But the phenomenon that occurs at the moment is in fact many premarital sexual behaviors were committed by adolescents who are dating. The inducement or lover requests are a motivation to have sexual intercourse, where persuasion and seduction to sexual intercourse occurs in women (Mayasari \& Hadjam, 2000). Adolescent's wrong perspective on sexuality negatively impact the younger generation. In this case, adolescent girls are more vulnerable to the risks and disadvantages of these sexual offenders (Rahmawati, 2010).

Syani (in Hidayah 2011) stated that there are differences between men and women in showing premarital sexual behavior. Males tend to be more independent and interactive in the position of asking and pressing (forcing). Meanwhile, women are more dependent and unable to refuse sex demands. Nunally and Hawari (in Marini, 2003) concluded that one of the cause of the adolescents fell into the negative things like drugs, brawling, and free sex was a weak personality. The characteristics include low resistance to pressure; low self-esteem; less able to express themselves; receive feedback, criticized, respects the rights and obligations; less able to control their emotions and aggressiveness and cannot resolve the problems and conflicts well which is closely related to assertiveness.

In everyday life and in interpersonal relationships, someone is sometimes faced with a conflict between the desire to maintain a personal right and a desire to maintain good relations with others. This requires a specific form of interpersonal behavior that helps individuals achieve their goals without violating the rights of others or hurt others. This behavior was known as assertive behavior (Hastiarni, 2004).

Being assertive can mean to show firm attitude done politely with the intention to express thoughts, feelings, and opinions without being aggressive or defensive but rather directly and honestly and not being used by others (Guntoro, in Hastiarni, 2004). In sexual context, sexual assertiveness concept has been developed as an understanding of the communication strategies used by individuals, especially women to protect sexual health and independence that can be assumed that women have rights over their bodies and the right to express their sexuality (Rickert, Sanghvi, \& Wiemann in Kusumadewi, 2013). 
One of the factors that influence whether or not someone is behaving assertively is culture. Alberti and Emmons (Harisetyaningrum, in Hastiarni, 2004) stated that there is cultural differences roles in assertive behavior. According to Taylor (in Umiyati 2009) one of the factors that influence assertive behavior is culture. Culture is the complex understanding of a nation feeling which includes knowledge, belief, art, morals, law, customs (habits) and other traits obtained from the members of the society. Indonesia is a multiethnic and multicultural nation where each ethnic has typical customs, habits and language. The Javanese, tend to have a nrimo and resigned attitude towards life because it is a destiny that has been determined by God. Javanese people want conformity, concord and harmony mindset to live with mutual respect (Bratawijaya, 1997). In general it was found that most Javanese prefer to remain silent and avoid conflict rather than fight, because they tend to emphasize the unity and harmony in life. In contrast to Batak people, most people paradigm assume that their appearance or the way they interacts were rough. Actually the "rough" means Batak people talk and act firmly, in which they have a mutually reinforcing, influence and dominant attitudes (Tinambunan, 2010).

Research conducted by Hastiarni (2004) concerning the assertive behavior differences between Java Culture and Batak Culture resulted that there is a difference between the assertive behavior of Javanese Culture and Batak Culture. Batak women have higher assertive behavior than the Javanese woman. Therefore, researchers are interested to see the sexual assertiveness difference between Javanese adolescent girls and Batak adolescent girls.

\section{MATERIALS AND METHODS}

This research used t-test aimed to see the sexual assertiveness difference between Javanese and Batak adolescent girls. The samples used in this study are samples that fit to the characteristics of the population, namely: Javanese and Batak adolescent girls, aged 15-18 years old and lived in Medan. The sampling technique used in this study is incidental non- probability sampling technique. Data were obtained by using Skala Asertivitas Seksual untuk Perempuan Indonesia (Sexual Assertiveness Scale for Indonesian Women or SASPI) developed by Lubis and Oriza based on Sexual Assertiveness Scale (SAS). Scale or questionnaire consisted of two dimensions, initiative and rejection. Data analysis method used in this research is descriptive analysis, and the entire quantitative research data processing will be conducted using SPSS version 16.0 for Windows programs.

\section{RESULT AND DISCUSSION}

\section{A. Result Research}

Sexual Assertiveness Empirical and Hypothetical Data

Table 1

Batak and Javanese Adolescent's Sexual Assertiveness Statistic Descriptions

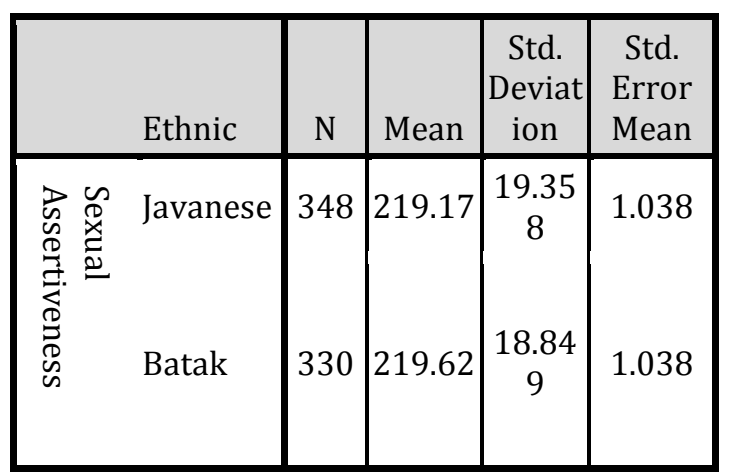

According to the table 1 we can see that the Javanese adolescent sexual assertiveness mean is 219.17 with a standard deviation of 19 358, while the Batak adolescent sexual assertiveness mean is 219.62 with a standard deviation of 18.849. Based on these tests result it can be seen that the Batak adolescent sexual assertiveness mean is slightly higher than the Javanese adolescent sexual assertiveness mean. 
Table 2

Javanese and Batak Adolescent Sexual

Assertiveness

Independent Sample T-Test Statistical Test Result

\begin{tabular}{|l|r|r|r|c|}
\hline \multicolumn{5}{|c|}{ Independent Sample Test } \\
\hline & $\begin{array}{c}\text { Mean } \\
\text { difference }\end{array}$ & $\begin{array}{l}\text { Sig (2- } \\
\text { talled) }\end{array}$ & df & $\mathrm{t}$ \\
\hline $\begin{array}{l}\text { Equal } \\
\text { variances } \\
\text { assumed }\end{array}$ & .455 & .757 & .676 & .310 \\
\hline $\begin{array}{l}\text { Equal } \\
\text { variances } \\
\text { not } \\
\text { assumed }\end{array}$ & .455 & .757 & 675.524 & .310 \\
\hline
\end{tabular}

Based on the results of the independent sample test table, it can be known that the $t$ arithmetic amounted to 0.310 and the significance value was 0.757 . Means that $P$ Value is bigger than $0.05(0.757>0.05)$, which mean there is no difference between Javanese adolescent girls' sexual assertiveness and Batak adolescent girls' sexual assertiveness.

\section{DISCUSSION RESEARCH}

Based on the research results it can be seen that the significant value was 0.757 . Means that $\mathrm{P}$ Value is bigger than $0.05(0.757>0.05)$, which mean there is no difference between Javanese adolescent girls sexual assertiveness and Batak adolescent girls sexual assertiveness. These results indicated that the hypothesis that stated there are assertive behavior level differences between groups of students from different ethnic group was rejected. This was in line with research conducted by Dewi (in Hastiarni, 2004) concerning assertive behavior differences between Javanese and Batak culture that resulted the hypothesis was also rejected, meaning that there is no assertive behavior difference between Javanese and Batak culture.

Based on previous studies it can be known that there is a significant relationship between assertive behavior and the influence of cultural differences. According to Rakos (in Amin, 2013) concept of creativity were related to culture in which a person grows and develops. In some culture a behavior seen as culturally assertive and appropriate. But the same thing cannot be accepted by the community with other cultural backgrounds. Furthermore Santosa (in Marpaung 2007) stated that one of the factors that affect assertiveness is culture. Culture was related to existing norms and provides a major influence on the formation of assertive behavior.

Assertiveness conducted in this study is assertive in sexual context. Sexual assertiveness is the ability to retain sexual right to be able to take sexual decisions while still giving appreciation to the rights of others and without hurting others or their partner and express themselves in an honest and proper way with a sense of comfort without feeling worried that interfering thus encouraging the establishment of equalities and similarities in the relationship with their partner (Lubis dan Oriza, 2005).

Batak people are not like most people paradigm who assume that their appearance or the way they interacts were rough. Actually the "rough" means Batak people talk and act firmly. Batak people were described as people who do not want to lose, loud, egoistic, open, spontaneous, aggressive and courageous to other people, especially to people outside the Batak tribe (Tinambunan, 2010). Thus, Batak people were known to not afraid of conflict with others because it had a doctrine that human beings are equal, no human being privileged over others.

Endraswara (2003) stated that the basic character of the Javanese is Nrima attitude. Nrima is to accept everything with spiritualpsychological awareness, without feeling nggrundel (grumbling about having disappointed behind). Whatever received is considered as a gift from God. They tend to accept with sincerity regardless of the outcome as long as effort has been made. If efforts fail, the Javanese tend to accept it as a lesson. Nrima was not without arduous efforts, but only as a psychological foundation. This means the Java has a moral obligation to respect the life order that exists in this world. They must accept life as it is while tried their best and foster inner peace as well as serenity in emotions. When Javanese people are faced with a conflict, they tend to deal with it by 
chose to be silent and not fussy (oppose) because the basic principle of most Javanese are "better live in harmony rather than have to mess with other people". This means that the Javanese were so uphold the hospitality attitude and valued harmony between people so they avoids conflict in order to achieve peace in life. Furthermore, Bratawijaya (1997) stated that the Javanese are known to have a slow, do not want haste in working, polite, gentle, friendly and patient attitudes.

Based on the description above, it can be concluded that Batak who straight forward will have higher assertive behavior than the Javanese. But the results of this study indicated there is no that sexual assertiveness difference among Javanese and Batak adolescents. According to Hardjowirogo (1983) shifting customs can be found in all traditional cultures around the world, including Javanese culture. Young people were pleased that there is a shift in value from day to day which fits the style and tastes of their lives. Furthermore, he also said that the psychological development in the Javanese community these days has been so advanced so that the Javanese community is now arguably free from the fear of doing something in the community. Java community sometimes based on their basic, natures, teachings, and education can be act according to the system of community life and must dare to face public opinion and ignore the words of others about them. Javanese community has now been transformed into a society that straight forward.

This research was conducted in the city of Medan, which means Javanese adolescents who live in Medan has been affected by the customs that exist in Medan where the dominant tribes is the tribe of Batak. Javanese were seen as people who do not straightforward and vary between speech and action. Javanese who have a habit to talk subtly and hiding away their feelings will be affected by the condition of Medan straightforward, open and spontaneous culture. Therefore, Javanese people who live in Medan have been adapted to Batak culture that dominant in Medan. According to research conducted by Palilati (2015) concerning the characteristics of the transmigrated Javanese and overseas
Javanese, Javanese who migrated out of the Java city still perform the Javanese customs. But in terms of communicating, Javanese, especially in urban areas have started to change; they started to talk with impolite words. This happens on their young people, although it was done with their peers and not with older people.

Research conducted by Marpaung (2007) concerning the assertiveness levels differences among Batak Toba's college students in Yogyakarta with Batak Toba's college students in Medan also resulted that the Batak Toba tribe living in Jogyakarta where the dominant ethnic group is the Javanese, experience changes in behavior, they become less assertive in communicating their opinion. Opens feeling or behave spontaneously is considered negative and immature in Javanese culture. Therefore, it can be seen, that living place can affect a person's culture and customs.

Java community who lived in Medan have a process of assimilation. Javanese change the elements of culture adjusting to the Batak culture. Matsumoto said (2008) people with different background who interact intensively for a long time cause the elements of culture change. Usually the minority culture will change the elements and adjusting to the culture of majority.

Based on the research results, it is also seen that the sexual assertiveness mean of the research subject is categorized to high. According to Marokoff (1997) there are some special factors were predictors of woman assertiveness in sexual context, one of which is the general assertiveness. There is a connection between general assertiveness and sexual assertiveness. If a person has a tendency to behave assertively in everyday situations or problems, then most likely he will have a high assertiveness in sexual problems. Lubis dan Oriza (2005) added that the younger generation tends to be more assertive because of gender roles learning that given these days is more modern than ever before.

This study use SASPI scale where the aitems has high social desirable and not accordance with culture in Medan. The contents of item scale its about sexual behavior, so it tend to cause a negative response. According to Azwar (2013) item contain high social desirable and cause 
negative response will not work as expected. Respondent tend to give the extreme answer, which is likely to cause the hypothesis is accepted, it means there is no difference sexual assertiveness between Javanese and Bataknese girls.

\section{CONCLUSION}

Based on the research results, the research hypothesis is rejected, where there is no difference between Javanese adolescent girls' sexual assertiveness and Batak adolescent girls' sexual assertiveness, where significant value is 0.757 (0.757 > 0.05).

In addition, it was resulted that the mean value in this study was high (Javanese adolescent's sexual assertiveness mean amounted to 219.17, while Batak adolescent's sexual assertiveness mean amounted to 219.62), so it can be concluded that sexual assertiveness of the research subjects is high.

Research hypothesis is accepted which means there is no difference sexual asertiveness between Javanese and Bataknese adolescent girls, its happen because the items scale have high social desirable.

For further research in order to get a more varied results, can be researched on the boys adolescent to view sexual assertiveness. The benefit is in order to know the extent of the differences between girls and boys adolescent.

Furthermore, it is better anyway to be able to use other demographic data such as age at first perform sexual behavior patterns with the opposite sex during adolescence. It is useful to enrich the knowledge in more detail about their sexual assertiveness variable.

The study area should be expanded rather than just in the city of Medan, in order to find the representation of the sexual assertiveness of girls adolescent in each region that would definitely be different.

\section{REFERENCES}

Amin M. \& Syuhad. (2013). Difference level of assertiveness between student who living in orphanage and student who living with parents. Thesis. Faculty of Psychology, Universitas Islam Negri Maulana Malik Ibrahim, Malang.

Azwar, S. (2003). Preparation of psychology scale. Bratawijaya, Thomas. (1997). Reveal and recognize javanese culture. Pradnya Pramita, Jakarta.

Endraswara, S. (2003). Characteristic in javanese culture, Hanindita Graha Widya, Yogyakarta.

Hardjowirogo, M. (1983). Javanese people, Haji Masagung CV, Jakarta.

Hastiarni, H. (2004). Difference of assertiveness between Javanese and Bataknese Culture. Thesis. Faculty of Psychology, Universitas Atma Jaya, Jakarta.

Hidayah, I.P. \& Kemala I. (2011). The effect of assertiveness toward premarital sexual behavior among girl. Skripsi. Faculty of Psychology, Universitas Sumatera Utara, Medan

Kusumadewi, N.S.(2013). Relatioship between sexual assetiveness with sexual risk taking behavior in college student in Jakarta. Skripsi. Faculty of Psychology, Universitas Binus, Jakarta.

Lubis, D.U \& Oriza, D. (2005). Sexual assertiveness Indonesian women, Skripsi. Faculty of Psychology, Universitas Indonesia, Jakarta

Marini, L \& Andriani, E. (2003). Difference of adolescent assertiveness in terms of parenting parents. Skripsi. Study Program of Psychology. Fakultas Kedokteran, Universitas Sumatera Utara, Medan.

Marpaung. (2007). Difference of level assertiveness between batak toba college student who living in Yogyakarta and Medan. Skripsi. Faculty of Psychology, Universitas Sanata Dharma, Yogyakarta.

Matsumoto, D. \& Juang L. (2008). Culture and psychology. 4th edition. Thomson Wadsworth. USA

Mayasari, F. Hadjam. (2000). Adolescent sexual behavior in dating terms of self esteem by sex. Journal of Psychology, No-2, 120-127.

Morokoff, P.J., Quina, K., Harlow, L.L., Whitmire, L., Grimley, D.M., Gibson, P.R., \& Burkholder, G.J., 1997, Sexual Assertiveness Scale (SAS) for Women: Development and Validation, 
Journal of personality and social psychology, No.4, Vol.73, 790-804.

Palilati, Siskawati. (2015). Characteristic of transmigration javanese people and foreign javanese people: comparison study in Gorontalo. Skripsi, Faculty of Social Sciences, Universitas Negri Goronatolo, Gorontalo

Rahmawati, Linda. (2010). Adolescent problem against the issue of sexuality. Retrieved Nov, 2016 from https://mardiya.wordpress.com/2010/12/ 02/pemahaman-remaja-terhadap-masalahseksualitas-oleh-lindarahmawati/ Sarwono, S.W. (2000). Adolescent psychology. PT. Raja Grafindo Persada, Jakarta.

Tinambunan, Djapiter. (2010). Bataknese people rude? Development character and image, Elex Media Komputindo, Jakarta.

Umiyati. (2009). Differences of assertif behavior between javanese and dayak culture. Skripsi. Faculty of Psychology, Universitas Muhammadiyah Surakarta, Surakarta. 